\title{
STRENGTHENING INTERNATIONAL COMPETITIVENESS AND INVESTMENT GROWTH AS THE BASIS FOR A NEW MODEL OF SERBIAN ECONOMY DEVELOPMENT
}

\author{
Dejan Đurić ${ }^{1}$, Vladimir Mitrović ${ }^{2}$, Dragana Đurićc ${ }^{3}$,Jelena Ristić ${ }^{4}$ \\ *Corresponding author E-mail: ddjuric971@gmail.com
}

\begin{abstract}
A R T I C LE I N F O
Review Article

Received:02 February 2018

Accepted: 07 June 2018

doi:10.5937/ekoPolj1802731D

UDC 339.727:330.34(497.11)

Keywords:

investments, exports, globalization, international competitiveness, economic growth.
\end{abstract}

JEL: F21, F63, O40, Q17

\begin{abstract}
A B S T R A C T
Insufficient export activity and low level of investment in the formation of gross domestic product are a negative feature of the Serbian economy over a longer period of time. The global financial and economic crisis has shown that a sustainable model of economic growth, which was basically based on the growth of domestic consumption and imports and a low share of investments in the structure of the use of GDP, is an unsustainable until then. It has become clear that such a model must be replaced by a pro-investment and export-oriented model of economic growth.

Bearing in mind the trends in macroeconomic flows in the Serbian economy, it is clear that the increase in investment and the competitiveness of domestic production imposes itself as one of the most important tasks of economic policy in the future. In this sense, the main goal of this.
\end{abstract}

(C) 2018 EA. All rights reserved.

\section{Introduction}

Modern economies function in the conditions of the global market, where the success of each player depends on his ability to be competitive, innovative and flexible. In complex competitive relations that govern the world economic scene, small economies, such as the Serbian economy, must build their way to international success in improving the business and competitiveness of their businesses.

1 Dejan Đurić, Ph.D., Professor, Business School of Applied Studies Novi Sad, Vladimira Perića Valtera Street, no. 4, 21000 Novi Sad, Republic of Serbia, Phone: +381 638057420; E-mail:ddjuric971@gmail.com

2 Vladimir Mitrović, MSc Assistant, Faculty of Economics in Kosovska Mitrovica, Kolašinska Street, no. 156, 38220 Kosovska Mitrovica, Republic of Serbia, +381 69713 756; E-mail:vladam338@gmail.com

3 Dragana Đurić, Ph.D., Professor, Business School of Applied Studies Blace, Kralja Petra I Street, no. 70, 18420 Blace, Republic of Serbia,+381 658057420; E-mail:djdragana@ikomline.net

4 Jelena Ristić, Ph.D., Professor, Business School of Applied Studies Blace, Kralja Petra I Street, no. 70, 18420 Blace, Republic of Serbia, +381 63404202; E-mail:jelenazristic@yahoo.com 
Given that the Serbian economy has been confronted with a number of political and economic problems over the long period due to which the process of transition was delayed, all this, in conjunction with other negative factors, influenced its poor positioning in the international arena. In such circumstances, it is very important to create an incentive economic environment that will lead to the construction of an export-oriented economy, which would make companies easier to find their place in the international market. In this regard, a special emphasis is placed on the analysis of key factors for improving the competitiveness of the Serbian economy, with a special emphasis on the importance of greater participation of exports and investments in the structure of formation of gross domestic product of Serbia.

\section{Methodology}

Theoretical elaboration and the goals have influenced the authors of this paper to use descriptive, comparative-historical and analytical-synthetic methodology, whereby an attempt was made to consider and understand the problem. Furthermore, the analysis of the content of the adopted documents and the results of the previous research was used. The basic data sources are represented by statistics of external trade and investments. Materials of the Ministry of Finance of the Republic of Serbia, The World Economic Forum, The World Bank, Statistical Office of the Republic of Serbia and other relevant sources.

\section{Concept and factors of competitiveness of the economy}

The competitiveness of an economy represents the degree of success of its positioning within the global market. It is defined as the ability to achieve market success, leading to a highly productive economy and an improved living standard for the entire population. According to the OECD definition, competitiveness is a measure of the country's ability to produce goods and services under the international market test in free and equitable market conditions, while maintaining and increasing the real income of the population in the long run(Competitiveness in International Trade, OECD). Competition, therefore, represents a competition, a rivalry or a competition process aimed at achieving the best results of the country on the world market. In that sense, we can point out that competitiveness is a concept that explains why some countries are developing faster than others.

There are macroeconomic and microeconomic elements of competitiveness. Microeconomics refers to the competitiveness of the company and is reflected in the relative advantage over other enterprises (lower prices, better quality of goods and services, better sales network, better market knowledge, etc.). Microeconomic elements of competitiveness work directly on the productivity of the company. Unlike microeconomic, macroeconomic elements of competitiveness have an indirect impact on enterprises. This impact is achieved through macroeconomic policy (monetary and fiscal policy), social infrastructure and political institutions. At a macro level, national competitiveness or competitiveness of countries is defined as the country's ability to achieve faster economic growth than other countries and to increase social well- 
being so that its economic structure changes and effectively adapts to changing market conditions internationally.

In macroeconomic theoretical thought there are two notions of the concept of competitiveness: traditional and modern understanding (Rosić, Đurić, 2008).

Traditionally, competitiveness is understood as a national participation in the world market or world trade. Consequently, this makes competitiveness a game with a zero score, that is, one country can increase or improve its competitiveness, only at the expense of another country. In order to achieve this goal and increase exports, local labor prices are kept at a very low level and devaluation of the national currency is carried out. It is considered that cheap labor and cheap domestic currency make one country more competitive on the world market. However, this understanding of competitiveness is completely contrary to national economic progress and high living standards. Cheap labor only points to a lack of competitiveness and hampers economic development. By devaluation of the national currency, the whole nation pays a pecuniary tax through the sale of its national products and services at low prices, and the purchase of products and services at higher prices on the world market.

Contemporary understanding of the concept of competitiveness implies finding the answer to the question: what is the source, or what is the basis of national prosperity and living standard? The national standard of living is the result of the productivity of the given economy, measured by the value of goods and services produced per unit of total resources available to one economy (human capital, financial capital, natural resources). Therefore, productivity depends on both the value of manufactured national products and services, expressed at market prices, and the efficiency of their production.

If the previous notes are taken into account, then contemporary perception of competitiveness is reduced to productivity. Competitiveness based on productivity is in line with economic development and high living standards of the population, which means adequately paid labor, high capital gains, etc. Productivity, therefore, should be the real goal of every economy, not export by itself. Only the increase in exports of products and services, which can be efficiently produced and marketed, has an effect on increasing national productivity.

This competitiveness is not an isolated phenomenon, but an interdisciplinary phenomenon that links business strategy, macroeconomic policy, legal and regulatory reform, education, competition policy, and a host of other economic, business and social factors to create a unified strategic plan in order to create greater added value (Cvijanović, Mihailović, 2012).

As a relatively complex indicator (expression) of business performance, competitiveness depends on a number of factors. All these factors can be classified into external and internal factors of competitiveness.

External factors of competitiveness are: macroeconomic management (economic policy), infrastructure, legal environment and regulation, public sector and state 
administration (administration), education, taxes and contributions, financial system, special measures of support to enterprises. Internal factors of competitiveness include: managerial capabilities, human resources, productivity, profitability, innovation, quality, and so on (Ristić et al., 2017.).

At first glance, it is clear that many of the listed factors of competitiveness, and not just external, are under the direct control of governments. Aware of their responsibility for developing competitiveness, the governments of many countries are directly engaged in increasing the competitiveness of the economies of their countries. So, for example, The governments of Austria, Belgium, Canada, Finland, Germany, the Netherlands, New Zealand, Sweden and the United States are exploring the problem of competitiveness, publishing the results of competitiveness analysis of their countries' economies and defining strategies for increasing competitiveness.

\section{Analysis of the competitiveness of the Serbian economy}

In the analysis of the competitiveness of the Serbian economy, we rely on one of the most famous competitiveness indexes - the Global Competitiveness Index (IGC), developed by the World Economic Forum. The Global Competitiveness Index is based on Empire research that identified a wide range of parameters that affect the competitiveness of an economy. These parameters include macroeconomic and microeconomic factors as well as institutional development factors. All these parameters together contribute to the competitiveness of the national economy, defined as a set of institutions, factors and policies that determine the level of productivity of the country. Data is graded on a scale of 1 to 7 (1-worst grade, the 7-best estimate), which is also a range of possible values for all subindicators, and for the Global Competitiveness Index itself.

Research based on the Global Competitiveness Index is based on the assumption that competitiveness is a complex phenomenon influenced by many factors. Numerous factors that affect competitiveness are grouped into 12 pillars of competitiveness, which are organized into three groups.

The first group of pillars of competitiveness includes the so- Basic requirements. This group includes the following pillars of competitiveness: (1) institutions, (2) infrastructure, (3) macroeconomic stability, and (4) health and primary education. The second group is the so-called. Factors of increasing efficiency. This group consists of the following pillars: (5) higher education and training, (6) the efficiency of the commodity market, (7) labor market efficiency, (8) financial market sophistication, (9) technological readiness and (10) market size. The third group consists of the socalled. Factors of innovation and sophistication. This group includes columns (11) sophistication of business processes and (12) innovations.

The degree of development of the country, expressed as a gross domestic product per capita, determines the significance of certain groups of columns. For the least developed countries of greatest importance, the first group of columns, i.e. Basic requirements. In the case of medium-developed countries (including Serbia), in addition 
to the basic requirements, another group of columns is of great importance. Factors of increasing efficiency. For the most developed countries, the second and third group of competitiveness pillars are of paramount importance. Efficiency Factors and Factors of Innovation and Sophistication.

The Global Competitiveness Index (IGC), which has been in place since 2005, includes macroeconomic and microeconomic elements of competitiveness. As we pointed out earlier, macroeconomic factors of competitiveness act indirectly on the productivity of enterprises, while microeconomic factors act directly on productivity of firms.

The IGC defines two broad areas of macroeconomic competitiveness: (1) macroeconomic policy and (2) social infrastructure and political institutions, as well as three broad areas of microeconomic competitiveness: (1) business vision of the company, (2) quality of the business environment and (3) business development clusters. Thus, this index included factors of productivity and competitiveness enhancement in development processes involving institutions and business associations. Productivity and competitiveness of the country in the final instance are determined by the productivity and competitiveness of enterprises (Bošnjak, 2011).

Based on the annual reports of the World Economic Forum, we can see that Serbia, prior to the first wave of the global financial crisis, gained the IGK value of 3.90 in 2008, and for the next year (2009), IGK noticeably dropped to 3.77. After this period, there was a gradual recovery, in 2013. the IGC would drop again to the level of 2009, while in 2014. it would return to the level of 2008. In 2015. the minimum value of the IGK of 0,01 was realized, and next year (2016) the indicator of this indicator is markedly noticeable.

According to the report of the World Economic Forum on Global Competitiveness for 2017., in Serbia the IGK value was 4,14. Serbia took the 78th position in the ranking list, which includes 137 countries that entered the SEF analysis that year.

Table 1. The value of IGC for the Republic of Serbia and the countries of the region (2008-2017)

\begin{tabular}{|l|l|l|l|l|l|l|l|l|l|l|}
\hline Year & $\mathbf{2 0 0 8}$ & $\mathbf{2 0 0 9}$ & $\mathbf{2 0 1 0}$ & $\mathbf{2 0 1 1}$ & $\mathbf{2 0 1 2}$ & $\mathbf{2 0 1 3}$ & $\mathbf{2 0 1 4}$ & $\mathbf{2 0 1 5}$ & $\mathbf{2 0 1 6}$ & $\mathbf{2 0 1 7}$ \\
\hline Albania & 3,55 & 3,72 & 3,94 & 4,06 & 3,91 & 3,85 & 3,84 & 3,93 & 4,06 & 4,18 \\
\hline BIH & 3,56 & 3,53 & 3,70 & 3,83 & 3,93 & 4,02 & n.a. & 3,71 & 3,80 & 3,87 \\
\hline Bulgaria & 4,03 & 4,02 & 4,13 & 4,16 & 4,27 & 4,31 & 4,37 & 4,32 & 4,44 & 4,46 \\
\hline Croatia & 4,22 & 4,03 & 4,04 & 4,08 & 4,04 & 4,13 & 4,13 & 4,07 & 4,15 & 4,19 \\
\hline Hungary & 4,22 & 4,22 & 4,33 & 4,36 & 4,30 & 4,25 & 4,28 & 4,25 & 4,20 & 4,33 \\
\hline BJRM & 3,87 & 3,95 & 4,02 & 4,05 & 4,04 & 4,14 & 4,26 & 4,28 & 4,23 & n.a. \\
\hline Year & $\mathbf{2 0 0 8}$ & $\mathbf{2 0 0 9}$ & $\mathbf{2 0 1 0}$ & $\mathbf{2 0 1 1}$ & $\mathbf{2 0 1 2}$ & $\mathbf{2 0 1 3}$ & $\mathbf{2 0 1 4}$ & $\mathbf{2 0 1 5}$ & $\mathbf{2 0 1 6}$ & $\mathbf{2 0 1 7}$ \\
\hline Montenegro & 4,11 & 4,16 & 4,36 & 4,27 & 4,14 & 4,20 & 4,23 & 4,20 & 4,05 & 4,15 \\
\hline Romania & 4,10 & 4,11 & 4,16 & 4,08 & 4,07 & 4,13 & 4,30 & 4,32 & 4,30 & 4,28 \\
\hline Serbia & $\mathbf{3 , 9 0}$ & $\mathbf{3 , 7 7}$ & $\mathbf{3 , 8 4}$ & $\mathbf{3 , 8 8}$ & $\mathbf{3 , 8 7}$ & $\mathbf{3 , 7 7}$ & $\mathbf{3 , 9 0}$ & $\mathbf{3 , 8 9}$ & $\mathbf{3 , 9 7}$ & $\mathbf{4 , 1 4}$ \\
\hline Slovenia & 4,50 & 4,55 & 4,42 & 4,30 & 4,34 & 4,25 & 4,22 & 4,28 & 4,39 & 4,48 \\
\hline
\end{tabular}

Source: WEF (2008, 2009, 2010, 2011, 2011, 2012, 2013, 2014, 2015, 2016, 2017) 
Compared to the previous year, the value of IGC for Serbia increased by 0.17 , which dominantly influenced the improvement of Serbia's position for 12 places (Serbia ranks 90th in 2016, and in 2015 it was $94^{\text {th }}$ ).

Table 2. The ranking of Serbia and the countries of the region according to the "Global

Competitiveness Report"

\begin{tabular}{|l|l|l|l|l|l|l|l|l|l|l|}
\hline Year & $\mathbf{2 0 0 8}$ & $\mathbf{2 0 0 9}$ & $\mathbf{2 0 1 0}$ & $\mathbf{2 0 1 1}$ & $\mathbf{2 0 1 2}$ & $\mathbf{2 0 1 3}$ & $\mathbf{2 0 1 4}$ & $\mathbf{2 0 1 5}$ & $\mathbf{2 0 1 6}$ & $\mathbf{2 0 1 7}$ \\
\hline Albania & 108 & 96 & 88 & 78 & 89 & 95 & 97 & 93 & 80 & 75 \\
\hline BIH & 107 & 109 & 102 & 100 & 88 & 87 & n.a. & 111 & 107 & 103 \\
\hline Bulgaria & 76 & 76 & 71 & 74 & 62 & 57 & 54 & 54 & 50 & 49 \\
\hline Croatia & 61 & 72 & 77 & 76 & 81 & 75 & 77 & 77 & 74 & 74 \\
\hline Hungary & 62 & 58 & 52 & 48 & 60 & 63 & 60 & 63 & 69 & 60 \\
\hline BJRM & 89 & 84 & 79 & 79 & 80 & 73 & 63 & 60 & 68 & n.a. \\
\hline Montenegro & 65 & 62 & 49 & 60 & 72 & 67 & 67 & 70 & 82 & 77 \\
\hline Romania & 68 & 64 & 67 & 77 & 78 & 76 & 59 & 53 & 62 & 68 \\
\hline Serbia & 85 & 93 & 96 & 95 & 95 & 101 & 94 & 94 & 90 & 78 \\
\hline Slovenia & 42 & 37 & 45 & 57 & 56 & 62 & 70 & 59 & 56 & 48 \\
\hline
\end{tabular}

Source: WEF (2008, 2009, 2010, 2011, 2011, 2012, 2013, 2014, 2015, 2016, 2017)

According to the overall competitiveness measured by the Global Competitiveness Index, Serbia was ranked better than Bosnia and Herzegovina in 2017, which ranks 103th in the SEF ranking list. Of the other countries in the region, Montenegro has improved the value of IGK by 0.1 , and it was located just ahead of Serbia in the 77th position (last year it occupied 82nd position), while Croatia, with an increase in IGK value of 0.04 , retained the same 74th place on the ranking list as the previous year. Albania was also ahead in the list for five places, which was placed in the 75th position, with an increase in the IGK value of 0.12 points. Among the best placed economies in the region are Romania, which is this year in the 68th place with a deterioration of 6 places, then Hungary, which improved its position by 9 places, with an increase in the value of IGK of 0.13 points and Slovenia, which again improved its position and took 48th place on the SEF list.

Based on data from SEF Report for 2017, we can notice that, except for Romania, all countries in the region recorded an improvement in the value of IGC this year, which on average amounted to about $2 \%$ compared to last year's value. At the same time, Serbia recorded an increase of $4.3 \%$ of IGCs, which contributed to the reduction of lagging behind the region's average. It should be noted that improving the position on the ranking list is becoming more and more difficult as the economy moves to the upper half of the list, since much better progress is needed to reflect the same on the values of the soft and hard indicators used in calculating the IGC.

Regarding the measurement of Serbia's progress on the basis of the pillars of competitiveness, it can be noted that in 2017 there was an improvement in almost all the pillars of competitiveness SEF follows (only in the case of the "Health and Basic Education" pillar the same IGC value was achieved, as in the previous year). Improving Serbia's position on the SEF list is the result of the current perception of the business world about the country's ability to provide long-term stable economic growth. 
Table 3. Value of IGK by competitiveness pillars (2015-2017)

\begin{tabular}{|l|l|l|l|l|}
\hline Num. & Pillar of competitiveness & $\mathbf{2 0 1 5}$ & $\mathbf{2 0 1 6}$ & $\mathbf{2 0 1 7}$ \\
\hline 1. & Institutions & 3,2 & 3,3 & 3,4 \\
\hline 2. & Infrastructure & 3,9 & 3,9 & 4,1 \\
\hline 3. & Macroeconomic environment & 3,6 & 4,1 & 4,6 \\
\hline 4. & Health and basic education & 5,9 & 6,0 & 6,0 \\
\hline 5. & Higher education and training & 4,3 & 4,4 & 4,6 \\
\hline 6. & Efficiency of the goods market & 3,7 & 3,8 & 4,0 \\
\hline 7. & Efficiency of the labor market & 3,7 & 3,8 & 4,0 \\
\hline 8. & Development of the financial market & 3,2 & 3,4 & 3,6 \\
\hline 9. & Technological competence & 4,5 & 4,1 & 4,3 \\
\hline 10. & Market size & 3,7 & 3,6 & 3,7 \\
\hline 11. & Sophisticated business & 3,1 & 3,2 & 3,5 \\
\hline 12. & Innovation & 2,9 & 3,0 & 3,1 \\
\hline
\end{tabular}

Source: WEF $(2015,2016,2017)$

Among the pillars of competitiveness in which the index value is highest, the pillar "Macroeconomic environment" is highlighted. In this year, the index rose by 0.5 points in 2017, and the same increase occurred in 2016 compared to the previous year. These increases in the index of the observed pillar of competitiveness are the result of, in particular, successful fiscal consolidation and significantly better results in terms of the deficit of the state budget, the increase of national savings in GDP and the growth of the country's credit rating. However, despite the apparent progress in 2016 and 1017, the pillar "Macroeconomic environment" is one of the four pillars with the greatest lag in terms of the environment. Within the first four pillars, which together represent a group of basic factors of competitiveness, it is noticeable increase of the index value achieved by the pillar "Infrastructure". The progress of this pillar is the result of the higher assessments made in the survey on the quality of total infrastructure in the country, roads, port infrastructure, air transport traffic, and the quality of electricity supply.

All the pillars within the group representing factors of increasing efficiency were achieved with enormous progress, with the only increase in the index value at the "Market Size" pillar, somewhat less compared to the rest. The increase in the value of the index in the competitiveness pillars of this group was on average $3.8 \%$ in comparison with the previous year. The improvement recorded in these pillars of competitiveness suggests a slightly higher level of satisfaction of surveyed businesspeople compared to previous years. One explanation is that there has been real improvement in each of the pillars observed, but it should be kept in mind that these data represent an estimate obtained from the perception of the current state and as such do not necessarily reflect objective progress. The last two pillars of competitiveness, which according to the SEF methodology are factors of sophistication and innovation in business, have also achieved an increase in the value of the index. The increase in the index at the "Business Sophistication" pillar is also the second largest and contributing to the increase of the aggregate IGK for Serbia right after the pillar "Macroeconomic environment". Nevertheless, by comparing the average values recorded in the countries 
from the environment with the results of Serbia, we can notice that in spite of the marked progress in the pillars "Efficiency of the goods market", "Development of the financial market" and "Technological competence", there is still a lag (Bošnjak, 2011).

In the SEF report, in addition to data on the movement of IGCs and countries' ranking, there is also a list of the most problematic country-by-country factors. In the latest report, there is a partial change in the factors identified by the businessmen as the most problematic for business in Serbia. As in the previous year, the biggest problem is the amount of tax rates, while with a very small difference, the problem of the funding source took the second place. The problems of inefficiency of state bureaucracy and corruption took the third and fourth place. Compared with last year's survey, in 2017, as a minor problem, inadequate infrastructure, government instability and inadequately educated power ratios were assessed.

Based on the presented indicators on the degree of competitiveness of the national economy, we can conclude that, despite the positive trends from recent years, Serbia is still in an unfavorable competitive position, because there is still a lagging behind the countries of Southeast Europe, and this lag is even more pronounced in relation to the countries European Union. Bearing this in mind, the strategic goal of Serbia as a candidate for EU membership must be to increase the competitiveness of the economy. In order to achieve this goal, it is necessary to make permanent efforts in the direction of strengthening the key competitiveness factors, primarily those related to strengthening export activities and establishing a stimulating investment environment for investments.

In the future period of its development, Serbia will have to significantly increase the level of competitiveness of its economy by developing development processes to strengthen the factors that raise the level of productivity of the economy. Key measures and activities for increasing Serbia's competitiveness and exports must be: creating a stimulating business environment and attracting investors, strengthening cooperation and integration processes in the region and Europe, active export and industrial policies that strengthen competitive economic sectors and branches, improving infrastructure (primarily road and railways), education reform, etc.

\section{The need to build an export and investor-oriented model of economic growth}

The essential transition characteristic of the Serbian economy in the period up to the onset of the global financial crisis was reflected in the discrepancy between production and consumption, i.e. a constantly higher level of aggregate consumption than the level of national production (about 20\%). The structure of the use of GDP was characterized by high share of personal consumption and insufficient participation of fixed assets. In addition, the GDP growth of Serbia in the period from 2001-2008 based on the rapid growth of the service sector, which led to a low relative share of tradable goods in the sectoral structure of GDP formation. The consequences of this discrepancy have been reflected in the growth of the foreign trade deficit. 
The global financial and economic crisis has shown that a sustainable model of economic growth, which was basically based on the growth of domestic consumption and imports and a low share of investments in the structure of the use of GDP, is an unsustainable until then. It has become clear that such a model must be replaced by a pro-investment and export-oriented model of economic growth. The expansion of domestic demand, on which economic growth was based in the observed period, was funded and stimulated by high inflows of capital from abroad. Growth in demand was not accompanied by an appropriate expansion of production, primarily in sectors of the interchangeable part of the economy (such as the processing industry). This led to the fact that economic growth was accompanied by the growth of the foreign trade deficit, relatively high inflation and the rise in unemployment.

After a long period of achieving relatively high economic growth rates, with the outbreak of the global economic crisis in Serbia, there is a break in the current economic trends. The economic crisis has led to a fall in aggregate demand, a reduction in inflows of foreign capital, an increase in insolvency and a recession in the economy. Under such conditions, it became clear that a new model of economic growth must be formulated, which should enable changes in the structure of the creation and use of GDP in the direction of strengthening the sector of tradable goods and increasing the contribution of investments financed from national and foreign savings and the contribution of exports to Serbia's economic growth. Thus, a new model of economic growth should enable the achievement of higher rates of economic growth and a significant share of exports and investments in GDP formation. This will enable an increase in the level of employment and the creation of more new jobs, as well as a higher standard of living and poverty reduction in the country.

\section{Need for greater participation of the sector of commodities}

Based on the trends in foreign trade flows in the second decade of the 21st century, we note that the participation of Serbia's commodity exports is almost continuously increasing, which, with the stabilization of the share of commodity imports, has led to a significant decrease in the share of foreign trade deficit. However, this does not mean that there has been a strong progress in exporting activities in our country. We conclude this on the basis that Serbia's exports relative to GDP are still significantly lower than in similar countries of Central Europe. While exports of goods and services in Serbia amount to about 44\% of GDP, the share of exports to GDP in similar countries (Bulgaria, Czech Republic and Hungary) is around 80\%. Starting from the level of external debt of the country and the need to import raw materials and reproductive material for domestic production, the export coefficient would have to reach a value above $50 \%$ of GDP (Ministry of Finance of the Republic of Serbia, 2015). Accordingly, Serbia has a large area for export growth and a reduction in external deficit on this basis. In addition, export growth is a key driver of sustainable growth in Serbia's economy in the coming years, so double-digit export growth rates would signal that Serbia is on a sustainable path of growth (Quarter monitor no. 40, 2015). 
As we pointed out earlier, the sectoral structure of the formation of the GDP of Serbia in the first decade of the 21 st century was changed in favor of the service sector. The dynamics and structure of economic growth in the observed period was not in the function of creating new comparative advantages in the international exchange and intensification of the export activities of the national economy. The established economic structure was such that the service sector dominantly contributed to the growth of social production, while the contributions of the production sectors that produce interchangeable goods declined (Serbia Development Report, 2010, p. 43). Thus, for the economic growth of Serbia in the period after 2000, the service sector with the average rate is the most deserving growth of gross added value of $4.6 \%$ annually. The service sector increased its share of GVA from 52.6\% in 2001 to $63.5 \%$ in 2009. Within this sector, the largest expansion was achieved by the information and communication sector, the trade sector and the financial sector. In contrast, slower average growth in the sector of industry, as well as a decrease in its share in GVA from $23.3 \%$ in 2001 to $20.8 \%$ in 2009 . At the same time, there was a decrease in the share of the manufacturing industry in the creation of GVA (with $21,7 \%$ to $16.7 \%$ ). The share of gross agricultural value added in the total GVA also recorded a significant decline (from 19.5\% to 9.4\%). The sectors of tradable goods have reduced the share in the formation of gross added value from $37.6 \%$ in 2001 to $21.6 \%$ in 2010 . This reduced the supply of goods for export, which increased the current account deficit. Thus, the contribution of the interchangeable part of the economy to the overall economic growth in the observed period was relatively modest.

Problems that limit the stronger strengthening of export activities of the Serbian economy were also present in later years. In the first place, we point out the inadequate structure of the domestic economy, that is, unfavorable export structure, which cannot ensure satisfactory competitiveness in the foreign market. In the structure of our country's exports, reproduction products are still predominant, products of low level of processing, so structural changes in the real sector are a basic prerequisite for raising export competitiveness to a higher level. During the period 2000-2015. there is a moderate structural improvement in domestic merchandise exports, which is reflected in the increase in the share of products of higher processing phases. The technological structure and factor intensity of commodity exports have been improved, but these changes have not significantly improved the structure of domestic exports and, consequently, created the conditions for its strong long-term growth. The level of quality of Serbian merchandise exports continues to lag behind the countries of the EU, and to a lesser degree also for the economies of the countries of Central Europe.

Strengthening the sector of commodities (industry, agriculture) implies, above all, technological modernization according to EU standards and productivity growth and living standards on this basis. This sector needs to gain a competitive advantage in the market for products with high added value, instead of producing and exporting various raw materials and semi-finished products. Given that the structural characteristics of the economy are a permanent source of economic instability and an obstacle to economic 
recovery and a stable long-term growth, and that the existing sectoral structure of the economy has not realized the efficient use of domestic resources, the process of structural reforms needs to be speeded up. Changing the sectoral structure of GDP requires an absolute and relatively fixed investment increase in the medium and long term, which is possible through the growth of domestic savings and a greater inflow of foreign investments as the main sources of financing the required level of investment. The change in the current economic structure with the construction and modernization of economic infrastructure is an imperative from the point of view of economic growth and employment, balancing the balance of payments and sustainable external stability.

\section{The structure of the use of GDP - the need for greater share of investments}

The relatively high growth rates of gross domestic product achieved in the first decade of the 20th century were primarily based on the growth of domestic consumption. High economic growth, as the main indicator of economic success in this period, was achieved with the growing fiscal and foreign trade deficit, a high level of inflation, low domestic savings and a high level of public spending and external debt. Economic growth was accompanied not only by internal but also by external macroeconomic imbalances. The deficits of the foreign trade and current account of the balance of payments had a high level, despite the rapid growth of exports. They were the result of a strong growth in imports based on the growth of domestic demand, due to the large increase in wages and public spending and strong lending activities of banks. Faster domestic consumption growth (above 7\% annually) from GDP growth (5.4\% averagely a year) caused the value of domestic consumption to exceed GDP by more than 20\%. Expansion of domestic demand was financed and stimulated, first of all, by high inflows of capital from abroad.

Thus, both personal and government spending generated GDP growth in the abovementioned period, while the increase in investment and exports was insufficient for faster economic growth and an increase in employment. Although a more favorable environment for business and investment of business entities was created, the current investment activity was still at a low level in relation to the development needs of the economy. Under such conditions, there could not be significant economic advancement, as fixed capital formation is the most important segment of GDP consumption from the point of view of development.

Table. 4. Serbia and neighboring countries: GDP growth 2014-2017

\begin{tabular}{|l|l|l|l|l|}
\hline Countries & $\mathbf{2 0 1 4}$ & $\mathbf{2 0 1 5}$ & $\mathbf{2 0 1 6}$ & $\mathbf{2 0 1 7}$ \\
\hline Serbia & -1.8 & 0.8 & 2.8 & 1.8 \\
\hline Environmental countries (weighted average) & 2.7 & 3.6 & 3.6 & 4.3 \\
\hline Albania & 1.8 & 2.2 & 3.4 & 4.0 \\
\hline BIH & 0.3 & 3.8 & 3.1 & 2.3 \\
\hline Bulgaria & 1.4 & 3.6 & 3.9 & 3.9 \\
\hline Croatia & -0.5 & 2.2 & 3.0 & 3.2 \\
\hline Hungary & 4.2 & 3.4 & 2.2 & 3.7 \\
\hline
\end{tabular}




\begin{tabular}{|l|l|l|l|l|}
\hline Countries & $\mathbf{2 0 1 4}$ & $\mathbf{2 0 1 5}$ & $\mathbf{2 0 1 6}$ & $\mathbf{2 0 1 7}$ \\
\hline BJRM & 3.6 & 3.9 & 2.9 & 0.0 \\
\hline Montenegro & 1.8 & 3.4 & 2.9 & 3.9 \\
\hline Romania & 3.1 & 4.0 & 4.6 & 5.7 \\
\hline
\end{tabular}

Source: EU Commission, European Economic Forecast - 2017

Unfortunately, low economic growth and insufficient participation of investments in the GDP structure still represent the main economic problem of the national economy. The data presented in the table show the achieved GDP growth of Serbia in the last four years. Observed in the regional context, we can conclude that Serbia is seriously lagging behind in terms of economic growth, not only for the developed countries of the European Union, but also in relation to the countries of our region. Although the economic growth recorded in 2016, the worst since the outbreak of the global economic crisis is still subdivided compared to the region. In 2017, the situation is even more unfavorable, as in Serbia there was a reduction in the rate of economic growth, while the countries of the region increased the rate of economic growth.

The main structural obstacle to establishing a high and sustainable sustainable economic growth is the insufficient participation of investments in GDP. A comparative analysis shows that the basic structural problem of the Serbian economy is a low share of investments in GDP. Namely, the current level of investment in Serbia is significantly lower than in the periods of intensified GDP growth from the previous decade, and is considerably lower than in the countries in the region. The average share of investment in GDP in countries in the region is almost $23 \%$, while in Serbia it is only about $18 \%$. The share of investment in GDP should increase from the current level of around 18\% of GDP to around $25 \%$ of GDP and be directed primarily to the interchangeable sectors of the economy. The low share of investments in GDP in Serbia barely provides for the restoration of production capacities and infrastructure (as approximately their depreciation is), that is, it does not allow high and sustainable economic growth.

The main reason for the lack of investment is a bad investment environment. For this, among other things, appropriate economic policies are needed, which are primarily: 1) to strengthen and ensure the achieved macroeconomic stability, and 2) to improve the investment environment. With the necessary improvement of the business environment, the state should also directly increase its public investments, from the current $3.3 \%$ of GDP to the region average of over $4.5 \%$ of GDP. The greatest danger to macroeconomic stability is still threatened by the fiscal side. Although the growth of public debt relative to GDP has stopped, this has happened when the debt has already exceeded $75 \%$ of GDP, which is an extremely high level for a country like Serbia. With so much public debt, any new external "shock" and recession, such as the one in 2008, would lead to its new growth of over $80 \%$ of GDP and there would probably be a crisis. As a result, fiscal consolidation must continue as long as the government deficit does not fall below $1 \%$ of GDP, and public debt begins to accelerate sharply. Also, the large public and state-owned enterprises (EPS, Srbija gas, RTB Bor, etc.) are still largely unreformed public finances 
and, consequently, macroeconomic stability - so the problems of these companies, after numerous delays, decisively resolve. In order to improve the investment environment, it is necessary to implement numerous reforms aimed at: education, health, increasing the efficiency of the judiciary, simplifying procedures and speeding up the issuing of licenses, combating corruption, and more (Quarter monitor no. 47, 2017.).

\section{Conclusion}

Competitiveness is the hallmark of modern business, which advances all countries and their businesses. The paper analyzes the competitive position of the Serbian economy in the international market, with special emphasis on the role of investments and exports and their impact on improving the performance of the domestic economy. The analysis focuses on key factors, elements and obstacles to improving business and competitiveness. In this respect, the main structural obstacle is the main structural obstacle to establishing a high and sustainable sustainable economic growth, which is insufficient participation of investments in GDP. In order to eliminate this obstacle and qualitatively improve the still insufficiently good investment environment, it is necessary to implement numerous reforms. Changing the present economic structure, with the construction and modernization of the economic infrastructure, is an imperative from the point of view of future economic growth and employment, balancing the balance of payments and sustainable external stability.

In the future period of its development, Serbia will have to significantly increase the level of competitiveness of its economy by developing development processes to strengthen the factors that raise the level of productivity of the economy. Key measures and activities to increase Serbia's competitiveness and exports must be: creating a stimulating business environment and attracting investors, strengthening cooperation and integration processes in the region and Europe, active export and industrial policies that strengthen competitive economic sectors and sectors, improving infrastructure, reforming education, and more.

\section{Conflict of interests}

The authors declare no conflict of interest.

\section{References}

1. Bošnjak M., (2011), Global economic and financial crisis and its impact on the economy and finances of Serbia, Ministry of Finance of Serbia, Belgrade.

2. Cvijanović, D., Mihailović, B., (2012), International marketing as a factor of the development of the export competitiveness, Monograph, Institute of Agricultural Economics, Belgrade. [in Serbian: Цвијановић, Д., Михаиловић, Б. (2012), Међународни маркетинг као фактор развоја извозне конкурентности]

3. Doing Business 2016, Measuring Regulatory Quality and Efficiency, Washington, The World Bank, 2015. 
4. Doing Business 2015, Going Beyond Efficiency, Washington, The World Bank, 2014.

5. Đurić, D., Ristić, J., Đurić, Dragana (2016), Foreign Direct Investments in the Role of Strengthening Export Competitiveness of the Serbian Economy, Economics of Agriculture, Vol. LXIII, N02 (353-740), ISSN 0352-3462, p. 531-545, Belgrade

6. Đurić, D., (2007), Conference - Challenges of Economic Policy of Serbia in 2007, Scientific Society of Economists with AEN and Faculty of Economics in Belgrade, Belgrade

7. Đurić, D., (2007), Strengthening and improving export activities as the most important goal of economic policy in 2007, Conference - Challenges of Economic Policy of Serbia in 2007, Scientific Society of Economists with AEN and Faculty of Economics in Belgrade, Belgrade.

8. Đurić, D., Đordjević, M., Tomić, R., (2012), National Economy, Alfa-Graf NS, Novi Sad.

9. Krstić, B., Stanišić, T., (2013), The Impact of Improving the Knowledge Economy on the Competitiveness of the Southeast European Countries, Industry, 41 (2)

10. Ministry of Finance of the Republic of Serbia (2011), Strategy for increasing exports of the Republic of Serbia for the period from 2008 to 2011, Belgrade.

11. Nikolić, G., (2014), Dynamics and qualitative changes in the trade of Serbia - Key link of progress, Backbone of the new development strategy of Serbia: without export there is no exit

12. Nikolić, G., (2014): Structural improvement of domestic merchandise exports, Journal of Finance, Ministry of Finance of the Republic of Serbia.

13. Ristić, J., Đurić, D., Cvijanović, D., (2017), Organizational structure of corporations and innovation as a determinant of competitive advantage, $13^{\text {th }}$ International Scientific Conference, The Teacher of the Future, International Journal vol. 17.1, Budva, Montenegro, p. 361-369

14. Quarter monitor no. 47, 2017, Belgrade.

15. Quarter monitor no. 40, 2015, Belgrade.

16. WEF (2017), The Global Competitiveness Report 2017-2018, available at: http:// www3.weforum.org/docs/GCR2017-2018/05FullReport/TheGlobalCompetitivene ssReport2017\%E2\%80\%932018.pdf (accessed on 10.12.2017.)

17. Statistical Office of the Republic of Serbia. [in Serbian: Републички завод за статистику], available at: http://webrzs.stat.gov.rs. (accessed on 02.01.2018.)

18. OECD, available at: http://stats.oecd.org/glossary/detail.asp?ID=399. (accessed on 01.12.2017.)

19. Serbia Development Report 2010. [in Serbian: Извештај о развоју Србије 2010], available at: http://mfin.gov.rs/UserFiles/File/dokumenti/IZVESTAJ\%200\%20 RAZVOJU\%20SRBIJE\%202010.pdf. (accessed on 02.12.2017.) 